\title{
Effects on invertebrate populations of drought- induced changes in estuarine water quality
}

\author{
Martin J. Attrill ${ }^{1, *}$, Michael Power ${ }^{2}$ \\ ${ }^{1}$ Benthic Ecology Research Group, Plymouth Environmental Research Centre, University of Plymouth, Drake Circus, \\ Plymouth PL4 8AA, United Kingdom \\ ${ }^{2}$ Department of Biology, University of Waterloo, Waterloo, Ontario N2L 3G1, Canada
}

\begin{abstract}
Between the years 1989 and 1992, severe drought conditions occurred in the Thames estuary catchment, significantly reducing freshwater flows into the estuary and affecting estuarine water quality. Long-term data assembled for water quality between 1977 and 1992 were combined with invertebrate abundance data obtained from the intake screens of West Thurrock power station over the same period. This allowed an examination of the influence of drought-induced changes in water-quality parameters on the populations of the most abundant mobile estuarine invertebrates. For 8 invertebrate species, seasonal and monthly means for pre-drought (1977 to 1988) and drought (1989 to 1992) abundances were calculated and tested for significant differences. Time-series data were used to estimate regression models explaining observed variations in populations of Carcinus maenas, Crangon crangon and Gammarus spp. during both periods. Stability tests were used to establish significant differences in pre-drought and drought models. Significant mean seasonal and monthly differences were found for C. maenas and Gammarus spp. in both winter and summer, with significant summer differences being apparent for C. crangon and Palaemon longirostris. Regression analyses confirmed these results for the modelled species and highlighted the significance of drought-related changes in temperature for all 3 crustaceans, with dissolved oxygen being an additional significant variable for $C$. crangon. The reported significant changes in abundance of the studied species during drought conditions have important implications for the structure and dynamics of estuarine food webs, as C. maenas, Gammarus spp., and particularly C. crangon, are either important predators on invertebrates and juvenile fish or major food items for estuarine fish species.
\end{abstract}

KEY WORDS: Thames · Drought - Models · Carcinus maenas · Crangon crangon · Gammarus · Crustacea $\cdot$ Cnidaria $\cdot$ Ctenophora $\cdot$ Temperature $\cdot$ Oxygen

Resale or republication not permitted without written consent of the publisher

\section{INTRODUCTION}

The distribution of species inhabiting estuaries is primarily determined by their responses to the highly variable physical and chemical environment indicative of the system (e.g. Wolff 1973). Whilst most research effort has concentrated on physiological (e.g. McLusky et al. 1982, Mangum 1986) and behavioural (e.g. Janssen \& Kuipers 1980, Roast et al. 1998) responses to tidal fluctuations in environmental variables (particularly

*E-mail: mattrill@plymouth.ac.uk salinity), the ultimate spatial extent of organism distribution within estuaries is determined by the degree of freshwater entering from major tributaries coupled with the physiological tolerance to low-salinity conditions (e.g. Remane \& Schlieper 1971). Seasonal cycles of precipitation and river flows also contribute to spatial and temporal variability in the structure of estuarine invertebrate assemblages (Chapman \& Brinkhurst 1981, Attrill 1998). However, observed spatial and temporal patterns may result from the indirect influence of flow on other physico-chemical variables, such as dissolved oxygen (Attrill et al. 1999). Furthermore, 2 similarly structured estuaries with different flow regimes 
can have markedly different levels of primary and secondary production (Montagna \& Kalke 1992).

Drought conditions can seriously reduce the amount of water flowing within river systems (Tallaksen et al. 1997), which is often compounded by abstraction for drinking-water supplies (Harding et al. 1995). Whilst the impact of such a reduction in water level has been investigated for river invertebrate communities (Extence 1981, Chessman \& Robinson 1987) and anadromous fish species (Heggenes et al. 1996, Armstrong et al. 1998), little consideration has been paid to the wider consequence of drought-induced reduction of freshwater flow on the distribution of estuarine invertebrates. Attrill et al. (1996) investigated the effect of low flows on tidal freshwater macroinvertebrates at the head of an estuary, and noted dramatic changes in community composition with small increases in salinity. They concluded that management policies should give wider consideration to the impact of drought on aquatic systems, but no major study has yet documented the impact of drought on fully estuarine invertebrate communities.

Drought conditions persisted in south-east England for a 4 yr period from 1989 to 1992 (Boar et al. 1995), resulting in record low levels of freshwater flowing into the Thames estuary (Attrill et al. 1996, Littlewood \& Marsh 1996) and affecting patterns of water quality further down the estuary (Attrill \& Thomas 1996, Attrill \& Power 2000). The Thames has been closely monitored since rehabilitation policies to mitigate anoxic and azoic conditions (Wheeler 1979) were introduced in the 1960s (Tinsley 1998). Consequently, the Environment Agency and precursory organizations (Kinniburgh 1998) have collated a comparatively long-term data set of water-quality measurements. Together with continuous records of fish and invertebrate populations from power-station intakes (Andrews 1984, Attrill \& Thomas 1996, Thomas 1998), the waterquality data form a comprehensive data set available for the comparative study of non-drought (1977 to 1988) and drought (1989 to 1992) periods in the estuary.

Accordingly, the aims of this paper were: (1) to assess the impact of drought-induced low flows on the populations of estuarine invertebrates by comparing data from the Thames estuary under drought and pre-drought regimes; (2) to construct models of these populations to determine which variables may be influencing any changes in the patterns of invertebrate distribution and; (3) to assess the application of these results to the management of aquatic systems under drought conditions.

\section{MATERIALS AND METHODS}

Sampling methodology. Samples of invertebrates were taken from the Thames estuary, UK, using the cooling-water intake screens of National Power's West Thurrock power station, located on the north bank of the mid-estuary, $67 \mathrm{~km}$ from Teddington weir (the input from the River Thames). Sample methodology has been outlined in Attrill \& Thomas (1996) and fully described in Thomas (1998). Information on the invertebrate species entrapped is documented in Attrill \& Thomas (1996) and Attrill et al. (1999). In summary, invertebrates (and fishes) entering the power station through the cooling water system were removed using rotating band screens and entrapped in nets below the outflow system. These nets were emptied every $30 \mathrm{~min}$ and the organisms present were identified and enumerated. For temporal comparison, the total catch over a $4 \mathrm{~h}$ survey period was pooled and data converted to the number of individuals per 500 million litres of water filtered (see Attrill \& Thomas [1996] for conversion equation).

Surveys were repeated approximately every $2 \mathrm{wk}$ at low spring tide between 1977 and 1992 inclusive, giving a continual data set for a 16 yr period.

Daily flow rates of freshwater into the estuary from the River Thames were measured by a fixed gauging station at Teddington weir. Water-quality parameters were obtained during water-analysis runs by the National Rivers Authority (now Environment Agency) sampling vessel along the length of the estuary. Sampling was completed throughout the year at varying intervals, increasing in frequency during summer as a result of concerns about seasonal changes in water quality. The mean time between samples was $2.6 \mathrm{wk}$, with $80 \%$ of all samples being separated by $\leq 3.0 \mathrm{wk}$. Minimum and maximum times between sample dates were 1.5 and 6.1 wk respectively. All measurements utilized here correspond to those for the zone off West Thurrock power station. The physical factors considered over the time period of the study are listed in Table 1, together with the reference for the relevant

Table 1. List of measured physico-chemical variables, together with sources of relevant analytical methods, where appropriate (na: not applicable)

\begin{tabular}{|ll|}
\hline Parameter & Source \\
\hline Freshwater flow & na (gauged flow over Teddington Weir $\left.\left[\mathrm{m}^{3} \mathrm{~s}^{-1}\right]\right)$ \\
Temperature & na (thermometer) \\
Salinity & US EPA (1983), Method 353.3 \\
$\begin{array}{l}\text { Dissolved oxygen } \\
\text { pH }\end{array}$ & HMSO (1980a) \\
Suspended solids & HMSO (1979) \\
Total oxidised nitrogen & US EPA (1980), Method 358.2 \\
\hline
\end{tabular}


analytical methodology. Salinity was mid-tide-corrected to allow valid temporal comparisons. Other variables (e.g. BOD [biological oxygen demand], phosphate, chlorophyll) were sporadically measured, but did not have a sufficient time series to be included in models.

Modelling details. The period 1989 to 1992 has been treated as atypical of the Thames estuary because of drought conditions prevailing in south-east England (Attrill et al. 1996). Low freshwater flows resulting from increased water abstraction have been shown to have significant effects on measured water-quality parameters (Attrill \& Power 2000). To establish the significance and seasonal pattern of possible effects on estuarine organisms, pre-drought (1977 to 1988) invertebrate population data were used to compute representative monthly means and associated $95 \%$ confidence intervals for each of: Carcinus maenas, Crangon crangon, Gammarus spp. (G. zaddachi and occasional G. salinus), Palaemon longirostris, Liocarcinus holsatus, Palaemon serratus, Pleurobrachia pileus and Aurelia aurita. Results were then compared to the monthly means obtained from available data during drought conditions (1989 to 1992). To further assess possible differences between pre-drought and drought periods, pre-drought and drought summer (July to September) and winter (January to March) means for all invertebrate populations were computed. Data used in the computations were tested for normality using the Shapiro-Wilk $W$-statistic before selection of the statistical tests used to establish any possible significant difference between the periods. The predominance of non-normal data required the use of the Mann-Whitney $U$-statistic, which has been shown to have good asymptotic efficiency when normality in the data cannot be assumed (Conover 1980).

Multiple linear-regression methods were then used to examine the significance of associations between invertebrate abundance and available physico-chemical variables for the drought period, and comparison was made to the pre-drought period. The estimated models postulate that abundance will be related to the physico-chemical conditions prevailing in the estuary at a given point in time, either because conditions are suited to a particular life-history stage of an organism or because conditions exceed the physiological tolerances of the organism, and are of the form:

$$
Y_{t}=a_{0}+a_{1} X_{1 t}+a_{2} X_{2 t}+\ldots .+a_{k} X_{k t}+\epsilon_{t}
$$

where $Y=$ available invertebrate data at a given point in time $(t), X_{1 t}$ to $X_{k t}=$ set of physico-chemical variates that explain $Y_{t}$ at time $t, a_{0}$ to $a_{k}=$ estimated model coefficients and $\epsilon_{t}=$ normally distributed error term with zero mean and unit variance (Draper \& Smith
1981). Outliers, resulting in non-normal residuals, were removed from model estimation data sets on the basis of box and whisker plots and Grubb's test (Grubbs 1969). For the Crangon crangon data set this resulted in the removal of 4 data points with values in excess of 38000 .

For statistical analysis, logarithmic (natural) transformations were completed on data, where necessary, to ensure conformance to an approximate normal distribution (Draper \& Smith 1981). To stabilize the variation in the Carcinus maenas data set for use in regression, a power transformation (Draper \& Smith 1981) was employed as follows:

$$
W=\left(Y^{\lambda}-1\right) / \lambda
$$

where $Y=$ original data and $\lambda=$ power transformation parameter chosen to minimize the $F$-value connected with the extra sum of squares as recommended by Draper \& Smith (1981). For the model results presented, $\lambda$ was estimated to be 0.30 .

Models were constructed from the set of environmental variables used to explain pre-drought fluctuations in abundance given in Attrill et al. (1999). In addition, models were tested specifically for possible inclusion of salinity, oxygen, temperature and $\mathrm{pH}$ variables as a result of observed water-quality changes during the drought period (Attrill \& Power 2000). Forward step-wise regression techniques (Draper \& Smith 1981, Dunn \& Clark 1987) were used to select final model variables from amongst the candidate set. The procedure selects, from among the feasible set, the independent variable with the highest $F$-value and enters it in the model provided the $F$-value exceeds a pre-specified F-to-enter criterion. At successive steps, previously entered variables are retained in the equation providing their associated $F$-values do not subsequently fail to exceed a pre-specified threshold ( $F$-toremove). Here the $F$-to-enter and $F$-to-remove values used were at the upper $\alpha=0.05$ point of the $F$-distribution, as recommended by Draper \& Smith (1981). Differing values of the $F$-to-enter and $F$-to-remove were used to test the effect of the choice of entry and removal criteria on the subset of model variables selected, and were found to have no effect. Backward elimination was further used to assess the stability of the selected independent variable set used in each regression and was found to have no effect on variable selection. Instrumental variables were used to capture seasonal influences on fluctuations in water-quality parameters. Variables representing each month were set equal to 1 if data were collected for that month, 0 otherwise (Koutsoyiannis 1977).

The Chow test (Chow 1960) was used to establish the stability of estimated pre-drought and drought models 

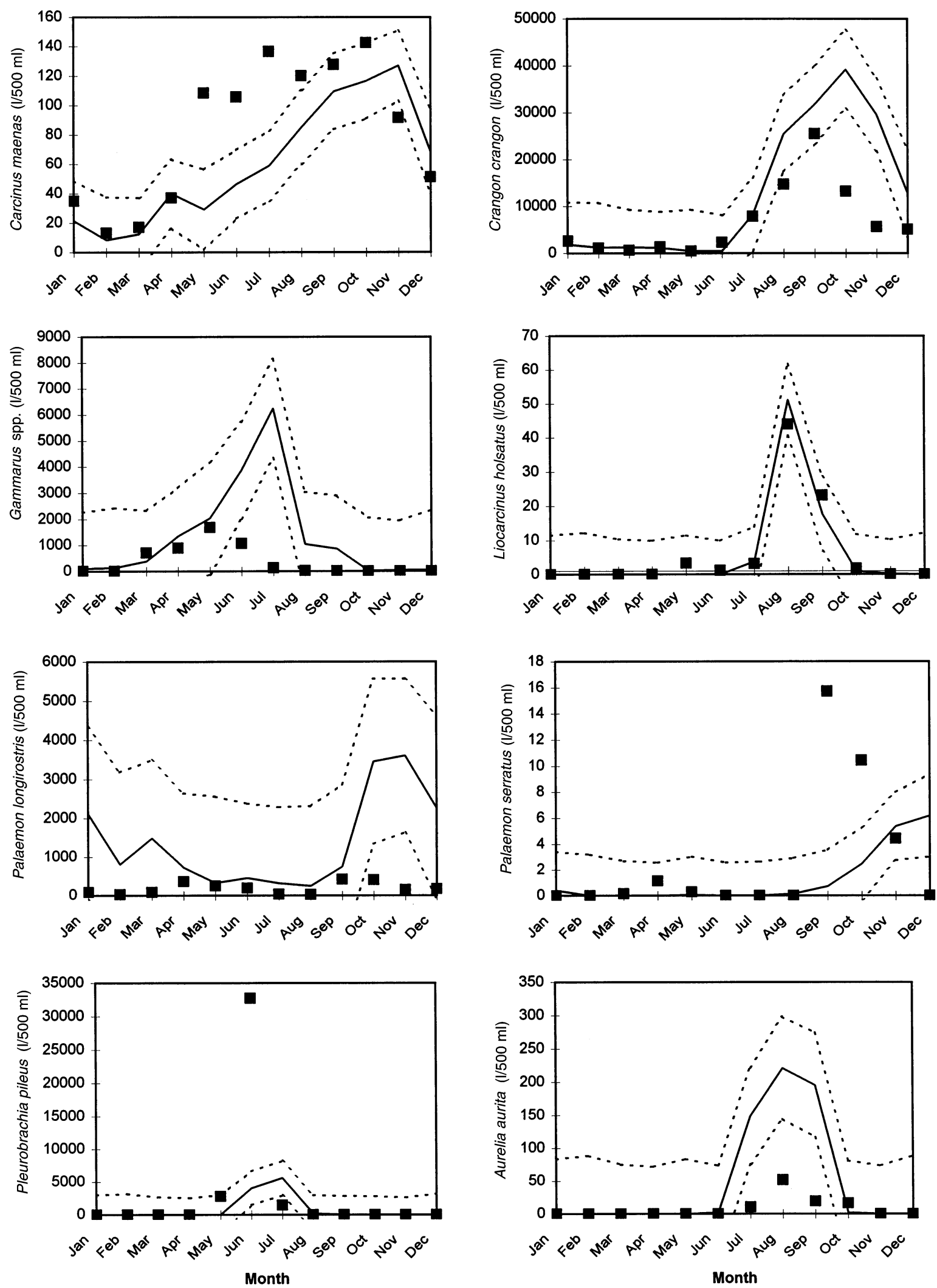

Fig. 1. Invertebrate population abundance (monthly means) during pre-drought and drought periods. Continuous lines $=1977$ to 1988 means; dashed lines $=95 \%$ confidence intervals; $=$ drought monthly means. Data here and in subsequent figures are individuals per 500 million litres of water filtered 
to changes in their respective estimation data sets. For pre-drought models the test was carried out by expanding the estimation data set to include all measurements made during the drought. Drought models were similarly tested by expanding their data-estimation sets to include all measurements taken in the predrought period. The Chow test is an $F$-statistic-based test. Test significance establishes that changes in the model variables have occurred as a result of some event (Koutsoyiannis 1977), and in this instance would establish the significance of drought effects on the populations of invertebrates studied.

The statistical assumptions underpinning ordinary least-squares were verified by examining model residuals for normality, serial correlation and heteroscedasticity. Royston's extension of the Shapiro-Wilk $W$-statistic (Royston 1982), applicable to sample sizes between 7 and 2000, was used to judge normality in model residuals. The Shapiro-Wilk statistic and its extensions have been recognized as amongst the most powerful omnibus tests for normality (D'Agostino 1986). Normalized versions of the Royston statistic were computed (Royston 1982), and may be compared to tabular values for the standard normal distribution to determine significance. Serial correlation was assessed using the runs test (Law \& Kelton 1991). The test is a direct assessment of the independence assumption for model residuals applicable when observations are not equally spaced in time. Values of the test statistic were computed following the procedure outlined in Banks \& Carson (1984). Finally, homoscedastic residuals were verified by plot- ting standardized residuals against fitted model values and examining the resulting plots for evidence of increasing or decreasing variance, as recommended by Draper \& Smith (1981).

\section{RESULTS}

The comparisons of drought and pre-drought mean monthly abundances for all invertebrates are presented in Fig. 1, with Mann-Whitney tests demonstrating significant differences in mean Carcinus maenas and Gammarus spp. summer and winter sample sizes and mean summer Palaemon longirostris and Crangon crangon sample sizes (Table 2). These seasonal differences are further reflected in model estimates for each species in the pre-drought and drought periods. Chow tests indicated that all models were sensitive to changes in the data set used for estimation, whether the changes in the estimation data set occurred as a result of adding the drought period observations to the pre-drought model estimation data set or vice versa (Table 3). The results are indicative of structural change in the underlying function defining the relationship amongst modelled variables and suggestive of a significant effect of drought on invertebrate abundance in the estuary. As a result, both pre-drought and drought models are combined on single plots as a means of highlighting the significant changes in population trends associated with the onset of drought (Figs. 2 to 4 ).

Table 2. Invertebrate population abundance (individuals per 500 million litres of water filtered (see 'Materials and methods; Sampling methodolgy' for details). Seasonal means (upper value) and inter-quartile range (lower values) for each population. Significant differences between mean pre-drought and drought abundance for winter (January, February, March) and summer (July, August, September) established using Mann-Whitney $U$-statistic. Underlined values: differences in $p$-values significant at $\alpha=0.05$

\begin{tabular}{|c|c|c|c|c|c|c|}
\hline \multirow{2}{*}{ Species } & \multicolumn{3}{|c|}{$\longrightarrow$ Winter -} & \multirow[b]{2}{*}{ Pre-drought } & \multicolumn{2}{|l|}{ Summer } \\
\hline & Pre-drought & Drought & $\mathrm{p}$-value & & Drought & $\mathrm{p}$-value \\
\hline $\begin{array}{l}\text { Carcinus } \\
\text { maenas }\end{array}$ & $\begin{array}{c}14.2 \\
3.5-18.5\end{array}$ & $\begin{array}{c}32.6 \\
9.0-52.0\end{array}$ & $\underline{0.006}$ & $\begin{array}{c}82.3 \\
41.5-104.0\end{array}$ & $\begin{array}{c}123.8 \\
53.0-160.5\end{array}$ & $\underline{0.026}$ \\
\hline Gammarus spp. & $\begin{array}{c}227.5 \\
30.0-405.0\end{array}$ & $\begin{array}{c}9.9 \\
6.0-8.0\end{array}$ & $\underline{0.001}$ & $\begin{array}{c}2865.3 \\
38.0-830.0\end{array}$ & $\begin{array}{c}57.9 \\
8.0-45.5\end{array}$ & 0.001 \\
\hline $\begin{array}{l}\text { Palaemon } \\
\text { longirostris }\end{array}$ & $\begin{array}{c}1497.8 \\
14.5-405.5\end{array}$ & $\begin{array}{c}88.9 \\
2.0-126.0\end{array}$ & 0.188 & $\begin{array}{c}434.4 \\
17.5-515.5\end{array}$ & $\begin{array}{c}96.4 \\
6.5-83.5\end{array}$ & 0.009 \\
\hline $\begin{array}{l}\text { Crangon } \\
\text { crangon }\end{array}$ & $\begin{array}{c}1496.7 \\
347.5-2067.5\end{array}$ & $\begin{array}{c}2212.4 \\
450.0-3390.0\end{array}$ & 0.428 & $\begin{array}{c}21240.0 \\
3562.5-27240.0\end{array}$ & $\begin{array}{c}8925.6 \\
3762.0-14610.0\end{array}$ & 0.039 \\
\hline $\begin{array}{l}\text { Liocarcinus } \\
\text { holsatus }\end{array}$ & $\begin{array}{c}0.3 \\
0.0-0.0\end{array}$ & $\begin{array}{c}0.0 \\
0.0-0.0\end{array}$ & 0.918 & $\begin{array}{c}23.7 \\
0.0-21.5\end{array}$ & $\begin{array}{c}24.3 \\
0.3-35.3\end{array}$ & 0.470 \\
\hline $\begin{array}{c}\text { Palaemon } \\
\text { serratus }\end{array}$ & $\begin{array}{c}0.1 \\
0.0-0.0\end{array}$ & $\begin{array}{c}0.1 \\
0.0-0.0\end{array}$ & 0.877 & $\begin{array}{c}0.3 \\
0.0-0.0\end{array}$ & $\begin{array}{c}4.5 \\
0.0-0.0\end{array}$ & 0.740 \\
\hline $\begin{array}{l}\text { Pleurobrachia } \\
\text { pileus }\end{array}$ & $\begin{array}{c}7.5 \\
0.0-1.0\end{array}$ & $\begin{array}{c}1.3 \\
0.0-1.0\end{array}$ & 0.487 & $\begin{array}{l}2108.5 \\
1.0-375.0\end{array}$ & $\begin{array}{c}501.4 \\
1.0-28.5\end{array}$ & 0.161 \\
\hline $\begin{array}{r}\text { Aurelia } \\
\text { aurita }\end{array}$ & $\begin{array}{c}0.0 \\
0.0-0.0\end{array}$ & $\begin{array}{c}0.0 \\
0.0-0.0\end{array}$ & 0.994 & $\begin{array}{c}187.1 \\
6.5-60.5\end{array}$ & $\begin{array}{c}28.6 \\
6.0-36.0\end{array}$ & 0.093 \\
\hline
\end{tabular}


Table 3. Carcinus maenas, Crangon crangon, Gammarus spp. Pre-drought and drought invertebrate model-regression diagnostics. Values of normalized Shapiro-Wilk or the runs test $Z$-statistic $>1.96$ or $<-1.96$ indicate non-normal or non-random residuals, respectively. Chow test was used to establish stability of estimated model coefficients when estimation data set was expanded. Tests here used estimated pre-drought and drought models, respectively, and each used expanded data estimation sets to include data from the other period. All reported $F$-statistic values were significant at $\alpha=0.05$

\begin{tabular}{|c|c|c|c|c|c|c|}
\hline \multirow{2}{*}{ Model } & \multicolumn{3}{|c|}{ Pre-drought } & \multirow[b]{2}{*}{$\begin{array}{c}\text { Shapiro-Wilk } \\
\text { normalised } W \text { - } \\
\text { statistic }\end{array}$} & \multicolumn{2}{|l|}{ Drought -} \\
\hline & $\begin{array}{c}\text { Shapiro-Wilk } \\
\text { normalised } W \text { - } \\
\text { statistic }\end{array}$ & $\begin{array}{l}\text { Runs test } \\
Z \text {-statistic }\end{array}$ & $\begin{array}{l}\text { Chow test } \\
\text { F-statistic }\end{array}$ & & $\begin{array}{l}\text { Runs test } \\
Z \text {-statistic }\end{array}$ & $\begin{array}{l}\text { Chow test } \\
\text { F-statistic }\end{array}$ \\
\hline Carcinus maenas & -0.602 & 1.248 & 5.90 & 0.614 & 0.362 & 5.86 \\
\hline Crangon crangon & -0.578 & 0.421 & 2.85 & 1.484 & 0.000 & 2.61 \\
\hline Gammarus spp. & -0.851 & -1.229 & 5.07 & 0.838 & -1.112 & 3.64 \\
\hline
\end{tabular}
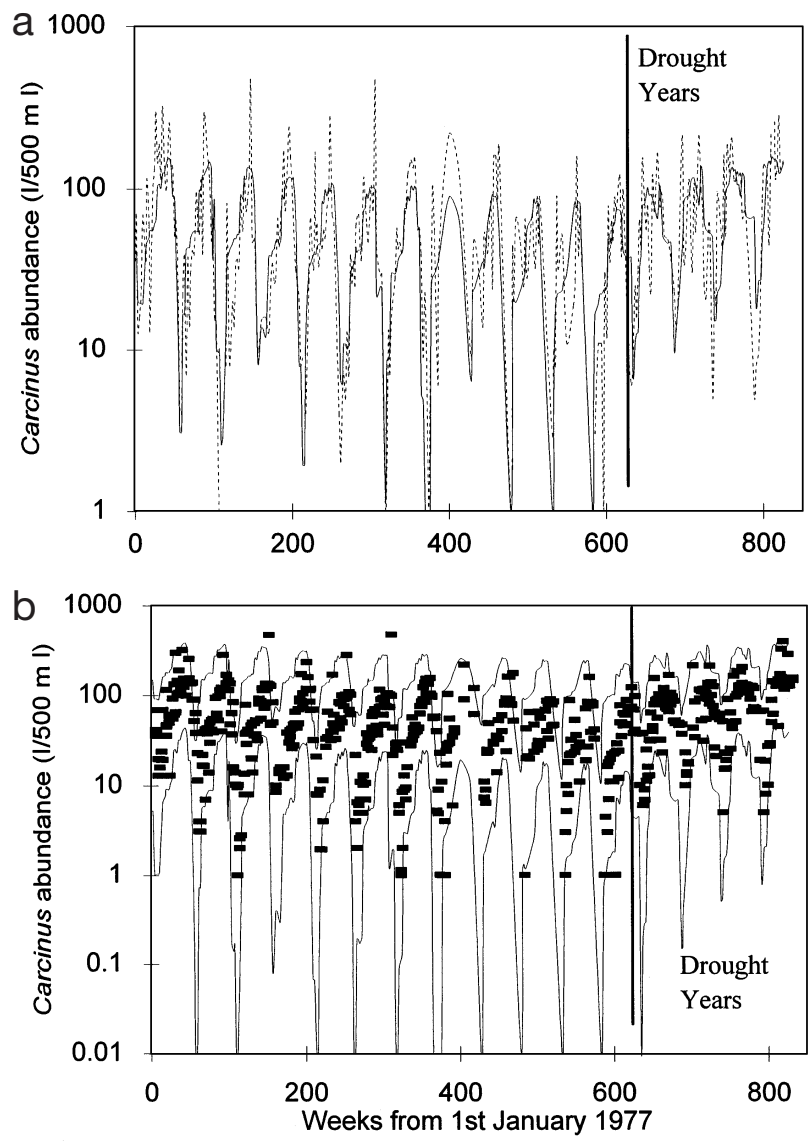

Fig. 2. Carcinus maenas. Model results for population in 1977 to 1988 (pre-drought period) and 1989 to 1992 (drought period). (a) Predicted versus actual values (dashed line $=$ actual values; continuous line $=$ model); (b) predictive $95 \%$ confidence limits of model (continuous lines), with actual values as individual datum points ( - )

Comparisons of the pre-drought and drought models in terms of significant model coefficients and proportion of explained variation are completed in Table 4, with variables entering into models as significant variables indicated. Results of the residual normality-testing, normalized version of the Shapiro-Wilk $W$-statistic and runs-test statistic are given in Table 3. Reported values provided no evidence for questioning the statistical adequacy of the estimated models. Standardized residual plots further confirmed that residuals were homoscedastic.

During drought periods, temperature becomes the dominant abiotic influence on species abundance (Table 4). Only Crangon crangon showed a response to any other abiotic variable, in this instance oxygen, which also played a significant role in determining pre-drought abundance. Seasonal effects are also in evidence; significant monthly variables occurred generally in the spring (March to June) period during the drought, whereas they were spread throughout the year in the pre-drought period. This may be related to the significant declines in flow evident during the same period and the consequent reduction in associated estuarine flushing. Trends also change between the pre-drought and drought periods, with Carcinus maenas switching from a slight downward trend in abundance to an increase (Fig. 2). There is a halt in the pre-drought decline in C. crangon abundance during the drought period (Fig. 3), whilst the Gammarus spp. population continues the declining trend in predrought abundance throughout the drought period (Fig. 4). For C. maenas and C. crangon there is also a notable reduction in the amplitude of variation in population abundance during drought years, due mainly to higher minima (Figs. $2 \& 3$ ).

\section{DISCUSSION}

The comprehensive data set obtained from the Thames estuary (for both invertebrate populations and physico-chemical variables) has enabled a detailed assessment of the effects of drought-induced changes in water quantity and quality on the population dynamics of the most abundant mobile invertebrate species inhabiting the mid-estuary region sampled by the power station. The drought period investigated 

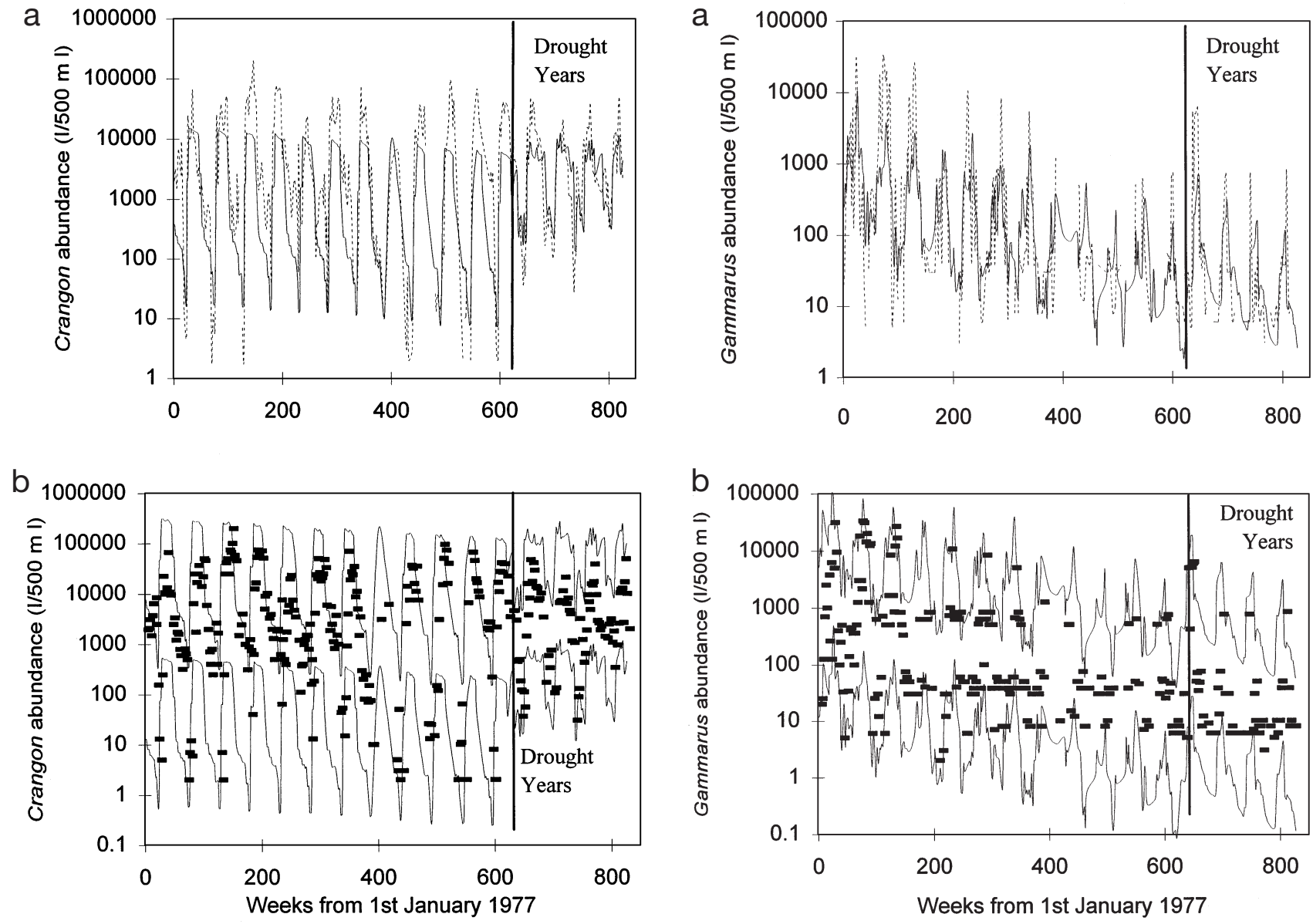

Fig. 3. Crangon crangon. Model results for population in 1977 to 1988 (pre-drought period) and 1989 to 1992 (drought period). (a) Predicted versus actual values (dashed line $=$ actual values, continuous line $=$ model); $($ b) predictive $95 \%$ confidence limits of model (continuous lines) with actual values as individual datum points ( $\mathbf{a})$

Fig. 4. Gammarus spp. Model results for population in 1977 to 1988 (pre-drought period) and 1989 to 1992 (drought period). (a) Predicted versus actual values (dashed line = actual values, continuous line $=$ model $) ;(b)$ predictive $95 \%$ confidence limits of model (continuous lines) with actual values as individual datum points ( - )

Table 4. Seasonal and physico-chemical variables featuring in pre-drought $(\mathbf{\square})$ and drought ( $\square$ ) fitted models for invertebrate populations, together with adjusted $\mathrm{r}^{2}$ for each model. Value of $\mathrm{r}^{2}$ adjusts for effect of additional explanatory variables and allows valid comparisons of explanatory power of different model forms. Seasonal variables: J-D = January-December; physico-chemical variables; $\mathrm{SA}=$ salinity; $\mathrm{DO}=$ dissolved oxygen; $\mathrm{TE}=$ temperature; $\mathrm{TR}=$ trigger, $\mathrm{WK}=$ weeks

\begin{tabular}{|c|c|c|c|c|c|c|c|c|c|c|c|c|c|c|c|c|c|c|}
\hline \multirow{3}{*}{ Carcinus maenus } & \multirow[b]{2}{*}{$\mathrm{J}$} & \multirow[b]{2}{*}{$\mathrm{F}$} & \multirow[b]{2}{*}{$\mathrm{M}$} & \multirow[b]{2}{*}{ A } & \multicolumn{4}{|c|}{ - Seasonal variables } & \multirow[b]{2}{*}{$\mathrm{S}$} & \multirow[b]{2}{*}{$\mathrm{O}$} & \multirow[b]{2}{*}{$\mathrm{N}$} & \multirow[b]{2}{*}{$\mathrm{D}$} & \multicolumn{6}{|c|}{ Physico-chemical variables } \\
\hline & & & & & $\mathrm{M}$ & $\mathrm{J}$ & $\mathrm{J}$ & A & & & & & $\mathrm{SA}$ & DO & TE & TR & WK & $\mathrm{r}^{2}$ \\
\hline & & & & & & & & & & & & & & & & & & \\
\hline Pre-drought & & घ & घ & & & & & - & घ & घ & घ & - & & & घ & घ & घ & 0.60 \\
\hline Drought & & & $\square$ & 口 & 口 & & & & & & 口 & & & & $\square$ & & 口 & 0.53 \\
\hline Crangon crangon & & & & & & & & & & & & & & & & & & \\
\hline Pre-drought & घ & घ & घ & घ & - & घ & घ & & & & & 匹 & & घ & & & घ & 0.65 \\
\hline Drought & & & $\square$ & $\square$ & $\square$ & $\square$ & & & & & & & & $\square$ & $\square$ & & & 0.58 \\
\hline Gammarus spp. & & & & & & & & & & & & & & & & & & \\
\hline Pre-drought & & & घ & घ & & & - & & & - & & & - & & घ & & - & 0.53 \\
\hline Drought & & & & $\square$ & $\square$ & $\square$ & & & & & & & & & $\square$ & & 口 & 0.43 \\
\hline
\end{tabular}


(1989 to 1992) was the driest recorded in the south-east of England (Littlewood \& Marsh 1996), which facilitates comparison of population fluctuations with those observed and described for the pre-drought period (Attrill et al. 1999). Additionally, significant changes in salinity, dissolved oxygen, temperature, $\mathrm{pH}$ (all higher), freshwater flow and suspended solids (both lower) during drought years imply that population changes can be related to drought-induced variations in water quality (Attrill \& Power 2000).

The species under investigation can be divided into 2 categories: those present in the mid-Thames estuary over the majority of the year (Carcinus maenas, Crangon crangon, Palaemon longirostris, Gammarus spp.) and species generally only occurring during the summer period (Liocarcinus holsatus, Palaemon serratus, Pleurobrachia pileus, Aurelia aurita). The significance of drought impacts varied, depending on the habit of the species. For all summer species there were no significant differences in mean abundance between drought and pre-drought periods, despite apparent large changes in the reported values (e.g. P. pileus in summer). This lack of significance (at the $\alpha=0.05$ level) largely resulted from the combination of high variance and small sample size concentrated into a few months.

For all 4 main invertebrate species resident in the mid-estuary region sampled, drought conditions resulted in significant changes in mean values during summer, with Carcinus maenas and Gammarus spp. population abundances also varying during winter. In addition, none of the 3 significant pre-drought models constructed by Attrill et al. (1999; C. maenas, Crangon crangon, Gammarus spp.) fitted the data during drought years, the fluctuations during this period (1989 to 1992) being described by alternative models.

During the drought period, catches of the shore crab Carcinus maenas were significantly larger in both winter and summer, this being a progressive increase over the drought years, as evidenced by the positive temporal trend in the model (Fig. 2). Additionally, the increased catches in winter resulted in higher minima during drought years, the consequence being a notably different model for C. maenas populations, with a contrasting range of significant seasonal variables. However, temperature remained the only significant physico-chemical variable to feature in both drought and pre-drought models, and highlights the importance of this parameter as a key environmental cue for the behaviour of the organism (Naylor et al. 1971, Atkinson \& Parsons 1973, Aagaard et al. 1995). Attrill et al. (1999) defined a 'trigger' instrumental variable in their model of C. maenas pre-drought populations in order to simulate a temperature threshold for activity, reporting this variable to be most significant at
$T=8^{\circ} \mathrm{C}$. This 'trigger' variable, however, does not feature in the C. maenas drought model, but its absence aids explanation of the increased minima noted for the model (Fig. 2). Temperatures were significantly elevated during the drought period (Attrill \& Power 2000), with water temperature dropping below $8^{\circ} \mathrm{C}$ on only 1 occasion $\left(7^{\circ} \mathrm{C}\right.$ : February 1991). It would therefore appear that because temperatures generally remained above the threshold for $C$. maenas activity over the drought period, increased numbers of crabs were caught during winter.

Populations of the brown shrimp Crangon crangon demonstrated similar patterns during the drought period to Carcinus maenas, with a reduced range in recorded abundances and a change in the temporal trend. C. crangon abundances were significantly lower in summer, exceptionally large swarms being more apparent during pre-drought years. In contrast, winter populations during drought years were maintained at a slightly higher level (Fig. 3), this stability being reflected in the lack of a significant temporal trend during the drought period. C. crangon tend to migrate to waters of higher salinity during winter (Bamber \& Henderson 1994). As salinity was significantly higher in the Thames during the drought period (Attrill \& Power 2000), it is probable that C. crangon were overwintering further up the estuary, thus increasing the number caught during winter in the mid-estuary region. Despite the elevated salinity levels during the drought years, and reports that the distribution of the shrimp is governed by responses to salinity (e.g. Lloyd \& Young 1947), this variable remained insignificant in the drought model for the species. Dissolved oxygen featured in both drought and pre-drought C. crangon models, reinforcing the suggestion that this variable is a major environmental cue for the species (Dyer 1978, Attrill et al. 1999). Temperature also proved significant during drought years. Water temperature has been reported as being a major controlling variable for the species (Boddeke 1968, Beukema 1992), but its absence from the pre-drought model suggests that this factor perhaps only becomes significant when increased above a certain threshold.

During the drought period, Gammarus spp. demonstrated a significantly reduced population size during both summer and winter. This difference was partly a function of a pre-drought downward trend reported by Attrill et al. (1999), resulting in a mean population several orders of magnitude smaller than was previously present in mid-Thames. However, a significant trend component in the Gammarus spp. model (Table 4) indicated that the population size continued to decrease during drought years. Additionally, the predrought model could not be fitted to the drought data, which were better described by an alternative model 
(Table 4), indicating that drought conditions had a significant effect on the Gammarus spp. population. Whilst this change may be explained by an upstream movement of the population following the reduction in flows (Attrill 1998, Attrill et al. 1999), the main Gammarus species comprising the samples from the Thames, G. zaddachi, is known to undertake summer reproductive migrations into more saline water (Hough \& Naylor 1992), and thus large numbers of individuals would be expected to be sampled at West Thurrock during the summer months. This was not evident during the drought period, and the population size was decreasing prior to the onset of drought, so a real reduction in Gammarus spp. abundance appears to have occurred in the Thames rather than a permanent movement to lower-salinity regions.

Any changes in the populations of Carcinus maenas, Crangon crangon and Gammarus spp. resulting from drought conditions, or other factors, would have subsequent implications for other components of the estuarine food web, as these crustacean species act as both predators and prey for a wide range of estuarine species. Many fish species in particular utilize C. crangon and Gammarus spp. as major prey items, whereas conversely both $C$. crangon and $C$. maenas are important predators of juvenile fishes. Of the most abundant fish species occurring in the mid-Thames estuary (Thomas 1998) bass Dicentrarchus labrax, sand goby Pomatoschistus minutus and dover sole Solea solea are all reliant to some degree on Gammarus spp. as a food source (Wheeler 1969, Aprahamian \& Barr 1985). However, the amphipods are a major constituent of the diet of smelt Osmerus eperlaunus and juvenile flounder Platichthys flesus because of movement by these fish species into less saline water where Gammarus zaddachi is the dominant invertebrate species (Attrill 1998). The reduction in Gammarus spp. abundance may, therefore, be a contributing factor to the reported decline in juvenile flounder abundance in the midThames estuary since the mid-1980s (Thomas 1998). Additionally, Gammarus spp. are initial hosts of the intestinal helminth parasite Pomphorhynchus laevis, with flounder and smelt being the 2 most heavily infected final hosts present in the Thames (Munro et al. 1998). Any significant changes in Gammarus spp. abundance could therefore influence the diet and parasite load of Thames fish species.

In European estuaries, Crangon crangon has been regarded as one of the most pivotal species in estuarine food webs (e.g. Costa \& Elliott 1991, Henderson et al. 1992). Because of its high abundance, the brown shrimp is the main food source for juvenile and adult stages of several major fish species, such as flounder, sand goby (Wheeler 1969) and juvenile gadoids (Kühl $\&$ Kuipers 1979). C. crangon numbers have been re- corded to crash following large influxes of whiting Merlangius merlangus (Berghahn 1996), whilst Elliott \& Taylor (1989) confirmed that predation on epibenthic shrimps results in bottom-dependency for several fish species. However, C. crangon has a further influence on food-web structure through predation on other invertebrates (e.g. Nilsson et al. 1993, Kamermans \& Huitema 1994) and settling juveniles of flatfish species (e.g. Modin \& Pihl 1996, Wennhage \& Gibson 1998). Such predation on juvenile fishes has also been recorded for Carcinus maenas (Ansell et al. 1999), so significant reductions or increases in either of these species due to drought conditions are likely to have consequent effects on the structure of estuarine food webs at several trophic levels. Certainly, the relationship between drought-induced changes in water quality and invertebrate and fish population-dynamics requires further investigation. Currently, however, it is clear that changes in the amount of freshwater entering an estuary can have significant effects on the populations of organisms inhabiting an estuarine system.

Acknowledgements. The authors wish to thank the Environment Agency for permission to analyse and publish the data. Support for completion of the work was provided by an NSERC Research Grant to M.P. Opinions stated in the paper are those of the authors and do not necessarily reflect those of any supporting agency or group.

\section{LITERATURE CITED}

Aagaard A, Warman CG, Depledge MH (1995) Tidal and seasonal changes in the temporal and spatial distribution of foraging Carcinus maenas in the weakly tidal littoral zone of Kerteminde Fjord, Denmark. Mar Ecol Prog Ser 122: 165-172

Andrews MJ (1984) Thames estuary: pollution and recovery. In: Sheehan PJ, Miller DR, Butler GC, Bourdeau Ph (eds) Effects of pollution at the ecosystem level. John Wiley \& Sons, London, p 195-227

Ansell AD, Comely CA, Robb L (1999) Distribution, movements and diet of macrocrustaceans on a Scottish sandy beach with particular reference to predation on juvenile fishes. Mar Ecol Prog Ser 176:115-130

Aprahamian MW, Barr CD (1985) The growth, abundance and diet of 0-group sea bass, Dicentrarchus labrax, from the Severn estuary. J Mar Biol Assoc UK 65:169-180

Armstrong JD, Braithwaite VA, Fox M (1998) The response of wild Atlantic salmon parr to acute reductions in water flow. J Anim Ecol 67:292-297

Atkinson RJA, Parsons AJ (1973) Seasonal patterns of migration and locomotor rhythmicity in populations of Carcinus. Neth J Sea Res 7:81-93

Attrill MJ (1998) The benthic macroinvertebrate communities of the Thames estuary. In: Attrill MJ (ed) A rehabilitated estuarine ecosystem. The environment and ecology of the Thames Estuary. Kluwer Academic Publishers, Dordrecht, p 85-114

Attrill MJ, Power M (2000) Modelling the effect of drought on estuarine water quality. Wat Res 34:1584-1594 
Attrill MJ, Thomas RM (1996) Long-term distribution patterns of mobile estuarine invertebrates (Ctenophora, Cnidaria, Crustacea: Decapoda) in relation to hydrological parameters. Mar Ecol Prog Ser 143:25-36

Attrill MJ, Rundle SD, Thomas RM (1996) The influence of drought-induced low freshwater flow on an upper-estuarine macroinvertebrate community. Wat Res 30:261-268

Attrill MJ, Power M, Thomas RM (1999) Modelling estuarine Crustacea population fluctuations in response to physicochemical trends. Mar Ecol Prog Ser 178:89-99

Bamber RN, Henderson PA (1994) Seasonality of caridean decapod and mysid distribution and movements within the Severn estuary and Bristol channel. Biol J Linn Soc 51: 83-91

Banks J, Carson JS (1984) Discrete-event system simulation. Prentice-Hall, Englewood Cliffs, NJ

Berghahn R (1996) Episodic mass invasions of juvenile gadoids into the Wadden Sea and their consequences for the population dynamics of brown shrimp (Crangon crangon). PSZN I: Mar Ecol 17:251-260

Beukema JJ (1992) Dynamics of juvenile shrimp Crangon crangon in a tidal-flat nursery of the Wadden Sea after mild and cold winters. Mar Ecol Prog Ser 83:157-165

Boar RR, Lister DH, Clough WT (1995) Phosphorus loads in a small groundwater-fed river during the 1989-1992 East Anglian drought. Wat Res 29:2167-2173

Boddeke R (1968) Forecasting the landings of brown shrimps (Crangon crangon) in the Netherlands. ICES (Shellfish \& Benthos Comm) K:8:1-4

Chapman PM, Brinkhurst RO (1981) Seasonal changes in interstitial salinities and seasonal movements of subtidal benthic invertebrates in the Fraser River estuary, B.C. Estuar Coast Shelf Sci 12:49-66

Chessman BC, Robinson DP (1987) Some effects of the 1982-83 drought on water-quality and macroinvertebrate fauna in the lower Latrobe river, Victoria. Aust J Mar Freshw Res 38:289-299

Chow GC (1960) Tests of equality between sets of coefficients in two linear regressions. Econometrica 28:591-605

Conover WJ (1980) Practical non-parametric statistics, 2nd edn. John Wiley \& Sons, New York

Costa MJ, Elliott M (1991) Fish usage and feeding in two industrialized estuaries - the Tagus, Portugal, and the Forth, Scotland. In: Elliott M, Ducrotoy JP (eds) Estuaries and coasts: spatial and temporal intercomparisons. Olsen \& Olsen, Fredensborg, p 289-297

D'Agostino RB (1986) Tests for the normal distribution. In: D'Agostino RB, Stephens MA (eds) Goodness-of-fit techniques. Marcel Dekker Inc, New York, p 367-420

Draper NR, Smith H (1981) Applied regression analysis, 2nd edn. John Wiley \& Sons, New York

Dunn OJ, Clark VA (1987) Applied statistics: analysis of variance and regression, 2nd edn. John Wiley \& Sons, New York

Dyer MF (1978) Studies of the cardiac and ventilatory behaviour of the brown shrimp Crangon crangon (L.). PhD thesis, University of Hull

Elliott M, Taylor CJL (1989) The structure and functioning of an estuarine/marine fish community in the Forth Estuary, Scotland. In: Klekowski RZ et al. (eds) Proceedings of the 21st European Marine Biology Symposium. Polish Academy of Sciences, Wroclaw, p 227-240

Extence CA (1981) The effect of drought on benthic invertebrate communities in a lowland river. Hydrobiologia 83:217-224

Grubbs FE (1969) Procedures for detecting outlying observations in samples. Technometrics 11:1-21
Harding BL, Sangoyomi TB, Payton EA (1995) Impacts of a severe sustained drought on Colorado River water resources. Wat Resour Bull 31:815-824

Heggenes J, Saltveit J, Lingaas O (1996) Predicting fish habitat use to changes in water flow: modelling critical minimum flows for Atlantic salmon, Salmo salar, and brown trout, $S$. trutta. Regul Rivers Res Manag 12: 331-344

Henderson PA, James D, Holmes RHA (1992) Trophic structure within the Bristol Channel: seasonality and stability in Bridgewater Bay. J Mar Biol Assoc UK 72:675-690

HMSO (1979) The measurement of electrical conductivity and the laboratory determination of the $\mathrm{pH}$ value of natural, treated and waste waters, 1978. Her Majesty's Stationery Office, London

HMSO (1980a) Dissolved oxygen in natural and waste waters, 1979 version: two methods. Her Majesty's Stationery Office, London

HMSO (1980b) Suspended, settleable and total dissolved solids in waters and effluents. Her Majesty's Stationery Office, London

Hough AR, Naylor E (1992) Biological and physical aspects of migration in the estuarine amphipod Gammarus zaddachi. Mar Biol 112:437-443

Janssen GM, Kuipers BR (1980) On tidal migration in the shrimp Crangon crangon. Neth J Sea Res 14:339-348

Kamermans P, Huitema HJ (1994) Shrimp (Crangon crangon L) browsing upon siphon tips inhibits feeding and growth in the bivalve Macoma balthica (L). J Exp Mar Biol Ecol 175:59-75

Kinniburgh J (1998) Physical and chemical characteristics. In: Attrill MJ (ed) A rehabilitated estuarine ecosystem. The environment and ecology of the Thames Estuary. Kluwer Academic Publishers, Dordrecht, p 27-48

Koutsoyiannis A (1977) Theory of econometrics, 2nd edn. Macmillan Press, London

Kühl H, Kuipers BR (1979) Qualitative food relationships of Wadden Sea fishes. In: Dankers N, Wolff WJ, Zulstra JJ (eds) Fishes and fisheries of the Wadden Sea. Balkema, Rotterdam, p 112-123

Law AM, Kelton WD (1991) Simulation modeling and analysis, 2nd edn. McGraw-Hill, New York

Littlewood IG, Marsh TJ (1996) Re-assessment of the monthly naturalized flow record for the river Thames at Kingston since 1883, and the implications for the relative severity of historical droughts. Regul Rivers Res Manag 12:13-26

Lloyd AJ, Young CM (1947) The biology of Crangon vulgaris L. in the Bristol Channel and Severn estuary. J Mar Biol Assoc UK 26:626-661

Mangum CP (1986) Osmoregulation in marine and estuarine animals - its influence on respiratory gas-exchange and transport. Boll Zool 53:1-7

McLusky DS, Hagerman C, Mitchell P (1982) Effect of salinity acclimation on osmoregulation in Crangon crangon and Praunus flexuosus. Ophelia 21:89-100

Modin J, Pihl L (1996) Small-scale distribution of juvenile plaice and flounder in relation to predatory shrimp in a shallow Swedish bay. J Fish Biol 49:1070-1085

Montagna PA, Kalke RD (1992) The effect of freshwater inflow on macrofaunal and meiofaunal populations in the Guadalupe and Nueces estuaries, Texas. Estuaries 15: $307-326$

Munro M, Whitfield P, Lee S (1998) Host-parasite interactions: case studies of parasitic infections in migratory fish. In: Attrill MJ (ed) A rehabilitated estuarine ecosystem. The environment and ecology of the Thames Estuary. Kluwer Academic Publishers, Dordrecht, p 141-167 
Naylor E, Atkinson RJA, Williams BG (1971) External factors influencing the tidal rhythm of shore crabs. J Interdiscip Cycle Res 2:173-180

Nilsson P, Sundback K, Jonsson B (1993) Effect of the brown shrimp Crangon crangon L. on endobenthic macrofauna, meiofauna and meiofaunal grazing rates. Neth J Sea Res 31:95-106

Remane A, Schlieper C (1971) Biology of brackish water, 2nd edn. E Schweizerbart'sche, Stuttgart

Roast SD, Widdows J, Jones MB (1998) The position maintenance behaviour of Neomysis integer (Peracarida: Mysidacea) in response to current velocity, substratum and salinity. J Exp Mar Biol Ecol 220:25-45

Royston JP (1982) An extension of Shapiro and Wilk's W test for normality to large samples. Appl Stat 31:115-124

Tallaksen LM, Madsen H, Clausen B (1997) On the definition and modelling of streamflow drought duration and volume. J Sci Hydrol 42:15-33

Thomas RM (1998) Temporal changes in the movements and abundance of Thames Estuary fish populations. In: Attrill MJ (ed) A rehabilitated estuarine ecosystem. The environ-

Editorial responsibility: Otto Kinne (Editor),

Oldendorf/Luhe, Germany ment and ecology of the Thames Estuary. Kluwer Academic Publishers, Dordrecht, p 115-140

Tinsley D (1998) The Thames estuary: a history of the impact of humans on the environment and a description of the current approach to environmental management. In: Attrill MJ (ed) A rehabilitated estuarine ecosystem. The environment and ecology of the Thames Estuary. Kluwer Academic Publishers, Dordrecht, p 5-26

US EPA (1983) Methods for chemical analysis of water and wastes. US Environmental Protection Agency, Washington, DC (EPA/600/4-79-020)

Wennhage H, Gibson RN (1998) Influence of food supply and a potential predator (Crangon crangon) on settling behaviour of plaice (Pleuronectes platessa). J Sea Res 39: 103-112

Wheeler A (1969) The fishes of the British Isles and North West Europe. MacMillan, London

Wheeler A (1979) The tidal Thames: the history of a river and its fishes. Routledge \& Kegan Paul, London

Wolff WJ (1973) The estuary as a habitat: an analysis of data on the soft-bottom macrofauna of the estuarine area of the rivers Rhine, Meuse and Scheldt. Zool Verh 126:1-242

Submitted: October 4, 1999; Accepted: March 21, 2000

Proofs received from author(s): July 18, 2000 